\title{
“Audição de Orfeu”, uma leitura do Canto VII da invenção épica de Jorge de Lima
}

\author{
Luciano Dias Cavalcanti* \\ Universidade Estadual de Campinas \\ Campinas, Brasil \\ Recebido em: 15/02/2019 \\ Aceito em: 17/03/2019
}

\begin{abstract}
Resumo: O mito de Orfeu foi revisitado por Jorge de Lima (1958) em Invenção de Orfeu numa tentativa de recuperá-lo em seus múltiplos significados na modernidade. $O$ poeta dedica um canto inteiro de seu épico à figura do citaredo trácio, o Canto VII - Audição de Orfeu, que pretendemos dedicar nossos esforços para sua análise. Em seu poema, o poeta procura explorar e transcender algumas das possíveis significações do mito grego, recriando-o ou simplesmente concordando com sua origem antiga. Em uma nova escritura, Jorge de Lima (1958) traz para a modernidade suas reflexões sobre o sentido do mito e do próprio Orfeu na construção de seu poema.
\end{abstract}

Palavras-chave: Invenção de Orfeu. Mito. Poesia.

\begin{abstract}
The myth of Orpheus was revisited by Jorge de Lima (1958) in Invenção de Orfeu in an attempt to recover it in its multiple meanings in modernity. The poet dedicates an entire corner of his epic to the figure of the thracian citaredo, Canto VII - Audição de Orfeu, which we intend to devote our efforts to his analysis. In his poem the poet seeks to explore and transcend some of the possible significations of the greek myth, recreating it or simply agreeing with its ancient origin. In a new scripture, Jorge de Lima (1958) brings to modernity his reflections on the meaning of the myth and of Orpheus himself in the construction of his poem.
\end{abstract}

Keywords: Invenção de Orfeu. Myth. Poetry.

Resumen: El mito de Orfeo fue revisitado por Jorge de Lima (1958) en Invenção de Orfeu en un intento de recuperarlo en sus múltiples significados en la modernidad. El poeta dedica todo un canto de su epopeya a la figura del mito, Canto VII - Audição de Orfeu, que queremos analizar aqui. En su poema, Jorge de Lima (1958) busca explorar y trascender algunas de las posibles significaciones del mito griego, recreándolo o simplemente de acuerdo con su origen antiguo. En un nuevo guión escritura, Jorge de Lima trae a la modernidad sus reflexiones sobre el significado del mito y del propio Orfeo en la construcción de su poema.

Palabras clave: Invenção de Orfeu. Mito. Poesía. 
O mito de Orfeu foi revisitado por Jorge de Lima (1958) em Invenção de Orfeu numa tentativa de recuperá-lo em seus múltiplos significados na modernidade. O poeta procura explorar e transcender algumas possíveis significações, recriando-o ou simplesmente concordando com sua origem antiga. Em uma nova escritura, Jorge de Lima (1958) traz para a modernidade suas reflexões sobre o sentido do mito e a respeito do próprio Orfeu, numa espécie de revalorização de concepções necessárias ao mundo moderno, que no momento da criação do poema presentifica uma série de conflitos provenientes dessa modernização: a multiplicidade do eu, o rompimento com a estética tradicional, a guerra, etc.. Desse modo, a figura de Orfeu está presente de forma constante no poema de Jorge de Lima (1958), seja de maneira explícita (pelo próprio mito como se pode ver em seu Canto VII - Audição de Orfeu) ou de maneira metafórico-simbólica (pelo significado do mito na sua representação figurada).

O mito de Orfeu é assim contado:

\begin{abstract}
Orfeu desceu ao mundo subterrâneo para resgatar sua amada e companheira Eurídice, que havia morrido ao ser mordida por uma serpente. Com seu canto e o dedilhar da lira, conseguiu comover os senhores do mundo subterrâneo de maneira que lhe devolveram a companheira, embora sob a condição de que ele não deveria voltar-se para olhá-la enquanto não tivesse alcançado a superfície. Forçado, porém, pela dúvida e pela saudade, ele desobedeceu esta proibição e por isso, Eurídice, que de fato o seguia, teve de voltar para o mundo subterrâneo enquanto ele retornou sem a companheira: é nessa forma que se encontra a saga, primeiramente em Virgilio (Culex 268-295) e Geórgias $(1,454 \text { até } 503)^{3}$.
\end{abstract}

Em uma das muitas versões do mito, Orfeu tenta voltar ao inferno, mas o barqueiro Caronte não o permite. Com a perda definitiva de Eurídice, o Poeta então resolve nunca mais se relacionar com nenhuma outra mulher. As Mênades, enfurecidas com esta atitude de extrema fidelidade à memória da esposa, o matam, despedaçando seu corpo. Punindo o crime das mulheres trácias, os deuses devastaram-lhe o país com uma grande peste. A devastação só se cessaria quando fosse encontrada a cabeça do vate. Após as buscas, um pescador a

\footnotetext{
${ }^{3}$ Trecho retirado do verbete - Orfeu: Arte e palavra, 1989, p. 87.
} 
encontra no rio Meles, na Jônia, em perfeito estado de conservação, onde foi erguido um templo em sua honra, cuja entrada era proibida às mulheres.

Orfeu participou da aventura dos argonautas, que pretendiam, sob a chefia de Jasão, conquistar o velocino de ouro, guardado por um dragão. Cada argonauta levava como apoio uma virtude que lhe era específica. Desse modo, Orfeu ingressa com o poder mágico de sua lira e de seu canto capaz de conter as discórdias dos homens e da natureza, e também ingressa nessa viagem como sacerdote e chefe espiritual, além de, com o seu canto, fornecer estímulo e ritmo aos remos. Esse episódio foi narrado por Apolônio de Rodes (séc. III a.C.) em sua obra denominada Argonáutica. Em seu primeiro livro, Apolônio mostra o antigo poeta sentado na proa do navio cantando sua teogonia. Como observa Brandão (1990), “os temas da viagem como forma de conhecimento e do canto como revelação do conhecimento estão aí presentes.” (BRANDÃO, 1990, p. 34)

O mito de Orfeu e as manifestações do espiritismo órfico subsistem através de seus motivos, temas e arquétipos nas mais diversas áreas artísticas, com singular predileção na literatura e na música. Em um sentido amplo, a arte órfica é concebida como criação livre e não como imitação.

O orfismo também vai se associar ao cristianismo ${ }^{4}$.

Acredita-se num contato entre ambos os movimentos e, senão influências, ao menos analogias inúmeras. A filosofia grega teria penetrado no cristianismo através do orfismo. Defende-se a tese de que São Paulo teria sido órfico antes de se converter ao cristianismo. Qual o significado da representação da figura de Orfeu nas catacumbas cristãs? É que, sem dúvida, os cristãos viam nele uma prefiguração de Cristo,

\footnotetext{
${ }^{4}$ É interessante notar que essa relação do cristianismo com o orfismo será aparente na obra de Jorge de Lima, como também em outros poetas como em Apollinaire, que em seu Bestiário, juntamente aos grandes temas órficos (a poesia, o amor e a morte), relaciona o mito de Orfeu a Cristo. Em uma nota a seu Bestiário, o poeta se refere assim a Orfeu: "Quando Orfeu tocava e cantava os animais vinham voluntariamente escutar seu canto. Baseado na magia ele adivinhou o futuro e o previu cristinianamente a vinda do Salvador". Desse modo, Apollinaire relaciona Orfeu a Cristo e ao poeta trazendo para este três características importantes: a de mágico, profeta e visionário, cujo canto é capaz de transformar o mundo. Além disso, Apollinaire em quatro momentos dá o nome de Orfeu a seus poemas e em um deles o relaciona diretamente à figura de Cristo: ORFEU "Que teu coração seja isca e céu, piscina! / Pois pescador, peixe de água doce ou salina/ Pode igualar-se por sua forma e sabor,/ Ao peixe divino, JESUS, Meu Salvador ?" (APOLLINAIRE, 1997, s/p). Além dessas considerações, é importante notar, nesse momento, a relação do Orfismo com a teologia paulina que, como sabemos, está diretamente relacionada à religiosidade de Jorge de Lima e de Murilo Mendes. Nesse sentido, a teologia paulina está presente na concepção religiosa e lírica destes poetas no sentido de ligá-las ao plano físico e real e não somente ao metafísico.
} 
um profeta iluminado que teria participado da revelação mosaica! Só isto explicaria tanta sabedoria num pagão.

Se, de um lado, o cristianismo repudia o panteísmo, a metempsicose, em compensação aceita a existência de um além, o pecado original, o dualismo do corpo e alma, sendo o corpo o cárcere da alma e este mundo um vale de lágrimas; a divisão do homem em uma parte boa e outra má, o aspecto titânico e dionisíaco, traduzido por São Paulo no antigo testamento o "homem novo" e o "homem velho".

Entre ambas as religiões se faz presente o mesmo ideal de salvação e de purificação servidas por uma estrutura eclesiástica. (TRINGALI, 1990, p. 22)

O grande estudioso da escrita de Orfeu, Marcel Detienne (1991), classificou-a como caracteristicamente inventiva e polifônica. Orfeu é o cantor do começo dos tempos, do tempo primordial 5 . Além disso, os órficos eram "renunciantes" e buscavam a idade de ouro, no pensamento órfico a grande divindade oracular é a noite recebedora do saber mântico mais alto. Diferentemente do mito de Prometeu, considerado o herói cultural que representa o esforço laborioso, a produtividade, o progresso ligado ao princípio da realidade, Orfeu representa o polo oposto.

Nesta lírica, Orfeu, o primeiro poeta, leva à poesia os seus significados característicos do canto, o ritmo, a melodia, o seu caráter divino, sonoro e musical, o que está intrinsecamente ligado à sua mitologia. $\mathrm{O}$ poeta, que quando canta encanta, constitui-se caracteristicamente como mago, utilizando-se do ritmo e da sonoridade no seu canto. Esta retomada do mito de Orfeu por Jorge de Lima (1958) se justifica e se associa a seu projeto utópico, no sentido de que serve como tentativa do poeta buscar o tempo da origem e também da linguagem desse

\footnotetext{
5 "O Orfeu do séc. IV a.C. era uma voz que não se assemelhava a qualquer outra. Enquanto os aedos e os citaredos celebravam altos feitos dos homens e dos deuses mas sempre em intenção de um grupo humano, a voz de Orfeu começou além do canto que recita e canta. Trata-se de uma voz anterior à palavra articulada, e cujo estatuto de exceção é marcado por dois traços: um designa Orfeu para o mundo da música antes do verso, a música sem palavra, um domínio onde ele não imitava ninguém, onde ele era o começo e a origem. Quanto à outra singularidade, ela é apontada nos Persas de Timóteo pela relação de engendramento: a lira de Orfeu não é um objeto técnico, construído, fabricado como o de Hermes que é orientado para o espaço socializado da música (festas e banquetes) ou para a atividade de arquitetônica como o instrumento dado pelo deus de Anfión, a lira-arquiteto que põe as pedras no lugar na construção da muralha. Muito ao contrário, foi Orfeu quem engendrou e procriou a lira ou a cítara. Sua atividade era a do teknoún e não do tektáinestha. O canto de Orfeu jorra como uma encantação original. Ela se canta mais em seus efeitos que em seu conteúdo. [...] Desde que a voz de Orfeu penetrou no mundo dos homens, para além do primeiro círculo dos guerreiros trácios, ela se escreveu, fez-se livro e foi escrita múltipla." (DETIENNE, 1991, p. 88)
} 
tempo. Nada mais coerente do que buscar essa poesia em estado original, no poeta primordial e em seus valores.

Jorge de Lima (1958) reservou um Canto inteiro a Orfeu, denominado Audição de Orfeu(Canto VII), que pretendemos dedicar nossos esforços para sua análise. A sua primeira estância é uma metáfora metalinguística que nos apresenta Orfeu (seu poema) a partir de uma linguagem sofisticada, quando aconselha o seu leitor a ler as entrelinhas do texto. Este canto mostra, principalmente, a linguagem poética do poema limiano, caracterizado por meio da figura de Orfeu. O soneto que abre o canto mostra como se deve lê-lo: a partir da transcendência e da imanência da linguagem poética. $O$ sentido de sua poesia está, portanto, além e aquém do campo denotativo das palavras, que não devem ser lidas de maneira literal.

\author{
A linguagem \\ parece outra \\ mas é a mesma \\ tradução. \\ Mesma viagem \\ presa e fluente, \\ e a ansiedade \\ da canção. \\ Lede além \\ do que existe \\ na impressão. \\ E daquilo \\ que está aquém \\ da expressão. \\ (LIMA, 1958, p. 791)
}

Para compreendermos melhor este soneto é importante reportarmos à estância I do Canto I, momento em que se estabelece uma proposição no poema em que o poeta nos apresenta seu herói, seu roteiro e seus objetivos, e nos diz qual é a ilha buscada por ele, uma ilha utópica. Etimologicamente, a palavra utopia recebe o significado de não-lugar (está fora do tempo e do espaço). A ilha buscada pelo poeta é também caracterizada de forma semelhante à utopia, pois ela é de aquém e de além-mar, portanto não está em um lugar determinado, não 
sendo possível localizá-la, como revelam os termos assinalados: “aquém (prep. e adv. do lado de cá de; inferiormente; abaixo; menos [antôn.: além]) e além (adv. acolá; mais adiante; mais longe [antôn.: aquém.] - s. m. lugar distante; outras terras; lugar fronteiro a outro - elemento de composição de palavras com o sentido de além de: além-mar; além-túmulo”. Dicionário Aurélio - 1986). Desse modo, a ilha limiana pode ser entendida como utópica, pois se situa em um lugar que não existe, reportando-nos para uma realidade irreal. É interessante notar que além da ilha não ter uma localização específica, ela é caracterizada por uma contradição ou pelo menos por um paradoxo, que é revelado por sua (não)determinação por meio de palavras antônimas, trazendo-lhe ainda mais obscuridade. A ilha também pode ser considerada total, mesmo não recebendo nenhuma localização; afinal, pode-se entender que ela ocupa um espaço que vai de aquém até além mar. Significado este que reforça ainda mais seu caráter utópico. O seu significado final a associa à busca e ao maior símbolo da fraternidade, o amor, como sugere a primeira estrofe, paródia do épico de Camões ${ }^{6}$.

Esta localização indefinida da ilha nos remete também a um tempo original, associado à busca de um espaço sagrado também sem limites e, portanto, primordial. No tempo primordial, dá-se a união entre passado, presente e futuro, caracterizando a celebração de um tempo mítico que contém a vida humana em sua totalidade. Nesse sentido, o passado se torna arquetípico, isto é,

\footnotetext{
${ }^{6}$ É interessante expormos aqui a concepção do lugar e o poder mágico da poesia concebido por Casais Monteiro, o que nos remeterá ao caráter metalinguístico do poema de Jorge de Lima. Assim diz o crítico: "Mas, de fato, embora sem tornarmos num sentido demasiado técnico, como não reconhecer como fonte da poesia uma zona que se encontra aquém - ou além - da coincidência superficial do homem com sua vida cotidiana? Como ignorar que o valor das palavras ganha, na poesia, um poder de comunicação que seria absurdo se através da linguagem não se estabelecesse qualquer entendimento do homem para o homem, e do homem para as coisas, que não existe nas palavras quando tomadas unicamente como sinais? É certo que, tal como a linguagem da razão, a poesia também procura uma verdade. Mas é uma verdade daquela dimensão humana em que dois mais dois não é igual a quatro. Nem por isso é uma linguagem do absurdo, muito menos do irreal. O mais estranho poder da poesia é que torna o mundo mais verdadeiro, exatamente porque, nela, as palavras não funcionam como sinais, ou como rótulos, mas como substitutos de alguma coisa que permanece por trás delas. Todas as afinidades que têm sido postas entre a poesia e as mais diversas formas do ocultismo, resultam exatamente de ser a poesia uma operação mágica, de não poder deixar de se reconhecer na transfiguração da palavra que se opera na poesia, qualquer forma de alquimia, uma transformação do mais vil no mais nobre metal". (MONTEIRO, 1965, p. 31)
} 
um passado que é potencialmente um futuro aparelhado para se encontrar com o presente. Desse modo, o herói dessa pretendida epopeia buscará conquistar o espaço primordial através da memória. Este aspecto da simultaneidade presente na poética moderna nos remete ao desejo do poeta moderno de querer reduzir distâncias através da possibilidade da aproximação espacial-temporal feita, muitas vezes, por suas metáforas, que associam termos dissonantes, e também pelo seu desejo de evasão do mundo em que vive. Esta comunhão entre os três tempos representa uma simultaneidade almejada pela poesia no intuito de eliminar os limites temporais como vemos dessa forma explícita na viagem empreendida pelo herói limiano.

\author{
Um Barão assinalado \\ sem brasão, sem gume e fama \\ cumpre apenas o seu fado: \\ amar, louvar sua dama, \\ dia e noite navegar, \\ que é de aquém e de além-mar \\ a ilha que busca e o amor que ama. \\ Nobre apenas de memórias, \\ vai lembrando de seus dias, \\ dias que são as histórias, \\ histórias que são porfias \\ de passados e futuros, \\ naufrágios e outros apuros, \\ descobertas e alegrias. \\ Alegrias descobertas \\ ou mesmo achadas, lá vão \\ a todas as naus alertas \\ de vária mastreação, \\ mastros que apontam caminhos \\ a países de outros vinhos. \\ Esta é a ébria embarcação. \\ Barão ébrio, mas barão, \\ de manchas condecorado; \\ entre o mar, o céu e o chão \\ fala sem ser escutado \\ a peixes, homens e aves, \\ bocas e bicos, com chaves, \\ e ele sem chaves na mão.
}

(LIMA, 1958, p. 627) 
Nesse sentido, Invenção de Orfeu apresenta, já no seu início, pelo menos três das temáticas mais importantes e constantes do poema: a do herói (representado pelo próprio poeta que cumpre uma missão - Barão ébrio -, o que lhe dá um caráter cristão por estar sujeito à vontade de Deus); a da viagem (que pode representar tanto a própria vida do homem, que metaforicamente viaja de seu nascimento até a morte, como também de uma viagem apenas imaginária e metalinguística) e a da ilha (que é a meta do herói e, como acreditamos, pode representar a metáfora central do poema).

Comecemos por delinear alguns elementos importantes presentes nesta estância. Destaca-se, primeiramente, a figura do Barão (como é caracterizado o herói do poema), que carrega, originalmente, o sentido de nobreza, conduzindonos a uma imagem característica do herói marcado por atitudes de coragem e de grandes feitos, remetendo diretamente ao herói camoniano d'Os Lusíadas. A relação deste com o herói limiano, no entanto, é em seguida desmistificada a partir de sua caracterização como ébrio, que imediatamente o associa à tradição poética da modernidade "O barco bêbado", de Rimbaud. Posteriormente, encontramos um elemento que se mostra de grande importância para todo o poema, uma chave $^{7}$, pois ela simboliza uma espécie de artefato capaz de restaurar a harmonia perdida pelo homem com a Queda. É a busca deste artefato e/ou da reconquista da perfeição que sustenta a aventura do herói-poeta em sua epopeia. Esta busca mítica fundamental da humanidade e suas referências intertextuais às epopeias clássicas também nos remetem ao poder revelador da palavra poética. Nesse sentido, o paraíso perdido é recuperado através da palavra, da poesia. E, desse modo, outro elemento importante no poema de Jorge de Lima (1958) se apresenta nessa estância, Orfeu. Herói de sua epopeia que se confunde com o próprio poeta e seu ofício, ele é a figura que orienta a busca da harmonia perdida.

\footnotetext{
${ }^{7}$ Em suas Memórias, o poeta se refere a uma chave que marcou suas lembranças. Isso pode significar que realmente Jorge de Lima está em busca desse momento, do retorno à infância perdida. Nesse sentido, a viagem empreendida pelo nauta-poeta em Invenção de Orfeu representaria a tentativa de reconquistar esse tempo paradisíaco da infância: "Lembrança da Casa-grande tenho muita que depois tratarei, como por exemplo da sala das chaves, chaves enormes de ferro penduradas a seus ganchos: trinta com os destinos, do paiol, do escritório, da despensa, da capela, capela de Santana onde havia missal no altar-mor e sacristia com gavetões de jacarandá." (LIMA, 1958, p. 99)
} 
Portanto, a chave buscada está dentro do próprio herói, é a própria poesia ou a palavra poética.

Podemos notar na estância II, da Audição de Orfeu, que a viagem empreendida pelo poeta e a ilha são igualadas, e vemos que a ilha criada pelo poeta é enfaticamente caracterizada por seu constante movimento e se metamorfoseia em um barco. Mas a ilha (poema) limiana não se transforma em qualquer barco, mas em um barco bêbado associando-se à tradição moderna da poesia representada por Rimbaud (1995). De acordo com essa tradição, notamos que a pretendida utopia buscada por Jorge de Lima (1958), representada por esta ilha, se opõe às tradicionais utopias renascentistas, que tem um caráter estático e definitivo, como comprovam as ilhas utópicas de Thomas Morus e de Campanela (1983). Portanto, será uma ilha livre, não se prendendo, em seu sentido metalinguístico, a nenhum padrão estético pré-estabelecido, sem métrica determinada ou temas fixos, opondo-se à tradição épica ocidental.

Para o poeta a utilização de uma linguagem hermética e simbólica em seu poema não impedirá que seus leitores o compreendam, porque, na realidade, a linguagem utilizada por ele não se diferencia de qualquer outra forma de expressão poética que pretende captar um momento poético. É por isso que o poeta pede a seu leitor que leia seu poema além do que está escrito, faça uma leitura das entrelinhas, da imaginação e do sonho, a linguagem de Orfeu. Nessa perspectiva, o hermetismo possibilita ao poeta dizer o que na linguagem comum não permite ser dito. Portanto, a não adequação do verbo poético à linguagem cotidiana ou do real é que lhe possibilita a recriação do mundo. Desse modo, a obscuridade presente em Invenção de Orfeu não está diretamente ligada à sua possível incompreensão.

Um tema importante nesta estância, que vale à pena nos determos mais, se refere à ebriedade, a associação do poema de Jorge de Lima (1958) a Rimbaud (1995) e seu Barco bêbado. Nessa associação apreendemos em Invenção de Orfeu uma característica marcante, o seu caráter dionisíaco. Jorge de Lima (1958) associa-se a Rimbaud (1995) de forma tão acentuada, que relaciona a ebriedade do poeta francês a seu projeto épico. Desse modo, o anseio de Jorge de Lima 
(1958) é alcançar, através de sua linguagem, o inatingível, na medida em que o poeta busca a renovação da linguagem de modo a mantê-la livre e ivre (ébria). Poderíamos dizer que é um projeto utópico do poeta, que antevê a comunhão total proporcionadapelo vento (espírito - sopro divino) e pela escrita ébria do barco-poema. Neste poema, a figura de Dante também surge associada ao personagem bíblico Jó, símbolo da paciência. Essas imagens sugerem não só o caráter dialógico de Invenção de Orfeu, mas também o trabalho paciente de Jorge de Lima (1958). A poesia é o veículo para chegada ao paraíso simbolizado pelo caminho para as Índias.

\begin{tabular}{l}
\multicolumn{1}{c}{ II } \\
Viagem e ilha \\
a mesma coisa \\
e um vento só \\
banhando livre \\
o poema ivre. \\
Guia e Alighieri \\
pisam a loisa \\
em que anda Jó. \\
Praticamente \\
loisa flutuante. \\
Nave de Îndia \\
desse maior, \\
rumo de um só \\
e de nenhum. \\
País comum. \\
(LIMA, 1958, p. 791)
\end{tabular}

Na estância III, o ambiente do poema é visivelmente surrealista, como demonstram a presença de "sois duplos" e novamente do "barco bêbado" de Rimbaud (1995). A direção tomada pelo poema-barco dá-se através do desejo e do sonho, e não segue nenhuma direção pré-determinada. Sua viagem segue mesmo sem bússola e sem mapa (como $O$ barco bêbado). É a multiplicidade e a incoerência que o poeta deseja captar em seu poema.

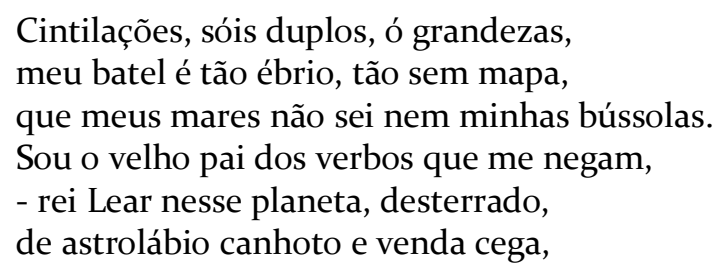


nos ocasos espelhos, e os azougues Do sangue destronado. Flutuando. Como julgar? Não há balança em paz. $\mathrm{O}$ jogo é um dom dos anjos informados que eu sou antes de mim. Ó solilóquio.

Secretos numes, causas, entidades, mãos vigilantes, vinde e dispersai-me, pelas fontes da vida e da expressão; que eu aspiro captar esses espelhos, incoerentes espelhos oniformes, indagado das trevas e das luzes. Emergem deles olhos que me espiam, entrados seres e outros vindos das anteportas e salas, da grei prévia. Vosso apólogo antigo me noviça vosso apresto me ofusca em circo irado.

Admoestador de alarmes consentidos, onde labora o ser (onde contínuas as manhas infantis e as borboletas rodeiam cofres cheios de raízes e sementes e bulbos maternais; onde tudo é perpétuo como o vento). $\mathrm{E}$, consequentes, eis os outros testes: a neblina no rio, os seios vistos, a asma colegial, as noites vivas, as falenas no teto... O poema nasce: Orfeu, Orfeu, Orfeu que me desperta.

Está ele de alvíssaras nos olhos, apenas reclinando, apenas arcoíris desmortalhado, mas ode, e arde. E aí estão, estes túneis tão compactos que cruzam o silêncio das palavras. Que relativas sombras o aspergiram? Que arcanos sucessivos o inspiraram? Que flamantes luzeiros imprevistos! Mas que fragor de brilhos profanados! Ó véu oculto em sol recém-finado! Ó monte sumo em Javas mergulhadas!

(LIMA, 1958, p. 792-793)

O ambiente apresentado pelo poeta é estritamente fantasioso, de modo que o passado infantil não será ordenado e nem permanecerá imóvel, será apresentado em imagens por meio da multiplicidade de visões num rearranjo de combinações de elementos que se ajuntam e se repelem, construindo um ambiente maravilhoso e complexo, tal qual um retrato feito por imagens muitas vezes contraditórias. Essa ambientação também está representada pelo tempo e espaço redefinidos, que ora se expandem, ora se comprimem. Por isso mesmo o 
mundo será reconstituído de forma diferenciada da imagem realista ("que eu aspiro captar esses espelhos, / incoerentes espelhos oniformes, / indagado das trevas e das luzes."). O próprio neologismo oniforme criado no poema e todo verso a que ele pertence revelam exemplarmente como é elaborado o poema: por incoerências e por uma forma onírica. Rompe-se, assim, com a pretensão de uma representação mimética do mundo. A memória do poeta deixa de representar apenas uma dimensão temporal real (retrato de um momento) e assume um caráter atemporal, materializado no poema: “onde tudo é perpétuo como o vento" (LIMA, 1958, p. 792-793).

Como uma verdadeira pintura surrealista, à paisagem comum é acrescentada mais um sol, ao mesmo tempo em que vemos o poema de Rimbaud (1995) fornecer o ritmo e a direção tomada pelo poema limiano, não uma direção determinada, mas aquela que preserva a liberdade do poema-barco, sem mapas ou bússolas. Outra vez, temos a mistura dos tempos (passado, presente e futuro) e fica nítido que, para o poeta, no homem de hoje está presente a criança de ontem, isto é, o Eu de hoje é a soma do passado e do presente. É interessante notar, como demonstra o último fragmento do poema referido, que o tempo da infância, presente na memória do poeta, tem um caráter de eternidade. Isso pode significar que este tempo passado (a infância) está amalgamada de tal forma no percurso da vida do poeta que ele a considera perpétua. Nesse sentido, a infância como memória consegue se tornar presente em todos os momentos da vida do poeta. Mas também pode significar, na poética de Jorge de Lima (1958), uma época sem tempo determinado ou que ocupa todos os tempos; portanto, se justifica como tema em toda sua obra poética. Se analisarmos o sentido da eternidade relacionada à adjetivação dada pelo poeta "como o vento" (LIMA, 1958, p. 792-793), inicialmente, isso pode nos parecer uma contradição, já que causa ambiguidade ao primeiro termo (pois o vento nunca é constante). Mas como é habitual, em Invenção de Orfeu, essa aparente contradição enriquece o termo adjetivado, no sentido de que a memória pode se caracterizar como o vento, que sopra ao poeta de tempo em tempo, ora com intensidade, ora com mais leveza - tal qual seu poema-barco, que em um momento passa por 
temporais e tormentas e, em outro, por calmaria, mas nunca está parado. Outra possível interpretação bem plausível se encerra na correspondência entre vento e sopro da criação divina. Nesse sentido, como está presente em todo poema, o poeta é concebido como um veículo de Deus e cria seu poema com ajuda deste. Esse aspecto também é típico da infância na obra do poeta que tanto pode aparecer com intensidade como de maneira suavizada.

Neste fragmento também se descreve o paraíso País comum e o poeta nos afirma que Orfeu o desperta trazendo boas novas. Associado à figura de Orfeu, enfatizada na evocação de seu nome por três vezes, e à valorização do tempo da infância rememorado pelo poeta, como aponta a referência à sua biografia, o poema apresenta uma relação intrínseca entre a visão órfica e a linguagem poética: “[...] O poema nasce:/ Orfeu, Orfeu, Orfeu que me desperta” (LIMA, 1958, p. 792-793).

É dessa experiência do sonho e da infância aqui associada a Orfeu, que o poeta desperta para a poesia. O mundo infantil do poeta é representado biograficamente pelas experiências do passado, associado ao mundo mágico, em que o poeta-menino se lembra de alguns acontecimentos importantes: a visão dos seios das escravas que banhava nos rios; a febre do menino doente; a imaginação noturna que vê falenas no teto - que traz novamente a emoção inspiradora do poema.

Orfeu é um ser premiado, pois traz boas novas vindas desse mundo imaginativo, noturno e infantil. Desse modo, pelo caráter simbólico que carrega, a utilização do mito no poema pode ser considerada manifestação artística e geradora de arte ${ }^{8}$. Em todas as civilizações, os mitos são fonte de inspiração para as mais diversas obras de arte, assim como as fantasias e criações imaginárias dos sonhos são também estímulos à atividade artística.

\footnotetext{
${ }^{8}$ Huizinga vai além dessa premissa nos dizendo que "seja qual for a forma sob a qual chegue até nós, o mito é sempre poesia. Trabalhando com imagens e a ajuda da imaginação, o mito narra uma série de coisas que se supõe terem sucedido em épocas muito recuadas. Pode revestir-se do mais sagrado e profundo significado. Pode ser que consiga exprimir relações que jamais poderiam ser descritas mediante um processo racional. [...] Tal como tudo aquilo que transcende os limites do juízo lógico e deliberativo, tanto o mito como a poesia se situam dentro da esfera lúdica." (HUIZINGA, 2005, p. 144)
} 
Na sequência, o poeta se diz sonâmbulo (um dos estados mais interessantes do sono, em que o indivíduo, mesmo dormindo apresenta atitudes próximas do estado de vigília) essa imagem é exemplar para a caracterização do poeta que escreve através da experiência do sonho, exercendo sua atividade criadora e transfigurando as experiências oníricas para o mundo da criação em estado de vigília. Para isso o poeta utiliza-se da metáfora do engenheiro noturno que representa a perspectiva limiana da criação, que une sonho e fantasia somados ao trabalho racional e organizador do texto poético, auxiliado, ainda, pela mão divina, demonstrando a presença mística em seu poema.

Compreendo, mão olímpica, teus signos,
teu apontar abaixo, aguda seta,
de sentenças à carne impermanente,
teus ciúmes dos seres naufragados,
teu ensino, teu certo movimento.
Persiste, mão olímpica, nos lábios
queimados por teus astros foragidos
Eu tíbio, eu tão sonâmbulo, eu recém,
eu esconso, eu incerto, opto por ti,
Sutil Pessoa Eterna. Sou tremor,
Cabeça, pés. Também meu pêlo sórdido.

(LIMA, 1958, p. 794)

Mais adiante, vemos que o poeta procura uma verdade soberana: ele deseja a volta ao paraíso depois de sua queda. A passagem do tempo (a circularidade temporal - o eterno retorno) causa dor, por isso o poeta deseja o rompimento com essa temporalidade, como aponta o verso: "escuta: esse vaivém da vida é dor" (LIMA, 1958, p. 795).

E tudo: ondas do tempo, almas floridas, árvores, flores, ninhos inda trêmulos, tudo lhe escuta as odes invocadas, mas cala seus murmúrios e seus ritos. Agora é a voz de alados mensageiros. Asas descem na luz dos céus pressagos, contempla-se a ilusão; graças, Espelho, que te elevaste em luminosa escada conduzindo a verdade soberana. Ó natureza de perpétuos sustos, escuta: esse vaivém da vida é dor. [...] já houve uma blandícia noutros tempos, 
hoje não há; não mais; então pervaga, pervaga em torno, em torno de ti mesmo.

(LIMA, 1958, p. 795)

Em seguida,o poeta apresenta a ideia de que não é possível viver e conceber sua poesia sem o sonho e reafirma o significado deste como desejo, já enunciado no início do poema soneto XXVI, do Canto I. Desejo de um mundo diferente do que se vive, um mundo melhor. De maneira metalinguística, o poeta nos revela como é construído o seu poema, através da febre, da memória, de conjeturas, montagem e desmontagem de coisas, da fé (lírica), da dor e com ajuda de um grande número de musas inventadas ou retiradas da tradição literária; formalmente, por meio da variedade métrica. O poeta também diz ter nascido no mesmo ambiente de qualquer outro ser humano, que já nasce, para ele, amortalhado, sem querer em um mundo que é um palco, onde a representação já é conhecida. O que diferencia o poeta das pessoas comuns é sua loucura, sua inspiração e seu sonho, que o faz se desvencilhar desse mundo opressor, onde os homens são manipulados feito fantoches para que o teatro do mundo continue o mesmo.

Sem amanhã virtual não sou possível, nem acontecimentos nem vindimas, apenas radiante, sem raízes.

Esta aragem, esta aragem, que borrasca dirá seu desvario ou seu cansaço? Metro de vário número, conubial de catres e de tronos. Conjecturas. Desmonto as coisas. Sabes da fé lírica ardendo as oblações e as arcas cruentas? Malgrado vejo perto, aqui, ali, nem sei, ó meu celeste abismo único. Dor cativa: sem noites de pestanas, sem pensar, sem calar, sem consolar-me, entre os astros ardentes tão distantes!

Será tudo severo, ó réu confesso e acusador; aqui tua equipagem de escarmentada nau e maré-magna. Em que chão de ontem? Que nevadas vides? E que jardins de espanto? Sob os vácuos? Vãmente aos sois cortantes? Vãmente? Ah! Coincidimos um passo sobre passos, 
e essa órbita constante. E esse delírio!

E esse dígito imenso destinado.

Sangraluz, Belatrix, Lis, Mira-Celi,

Vivantares, Liriana, ó meu poema!

Eis o vago tropel dos seres todos nascendo amortalhados sem querer.

Ali está o poeta: tem nos brandos lábios, a abelha vã, a abelha quase louca;

a abelha zumbidora. Sonha um duende, e mais além seu canto; nem ele ouve.

Mas com que passo lento e olhar sem vida partimos para o circo, ó pulso exangue! Ó! Ópera combinada, máscara em pranto, Vísceras de toureiros renegados!

E o mais esse lutar para cair.

(LIMA, 1958, p. 797)

O tempo presente matou as ternuras da infância, e o poeta passa por tormentas porque o mundo vive a presença da guerra e do fascismo. Por isso ele deseja uma vida solidária e fraterna e convoca as imagens do paraíso, como sugere sequencialmente um fragmento da mesma estância. A presença da guerra, demonstra também a reafirmação da temática social em Invenção de Orfeu, e aponta que Jorge de Lima (1958) não deixou de lado o elemento social de sua poesia pregressa.

Esse clima cinábrio abreviativo convocará os sangues, os desvios? Olharemos conjuntos esse mapa? Pulsaremos na artéria fraternal? Mão na mão, musa de astro, calor frio. Na blandícia das chuvas desce um seio, e entrementes nos sulcos das charruas percebemos os semens dos roteiros. Este clima demais calvário e leva quem o agrega? Essa voz indefinida?

Esse arcanjo banido, desfolhando-se? Aquiescência. No início havia a mancha. Inconsumptível mancha, nuvem nossa. E o céu pesado sobre. Éramos um! E amávamos os sóis antropomorfos, os lilases nos olhos, luas sempre, e o consolo tão bom nos calcanhares, e a leitura das relvas, nomes dados a essa pedra, a esse pomo. A esse coral. E havia o dia vindo, e a noite leve, e o peixe amigo, e a rocha deleitosa, 
e ametistas nas unhas, conivências entre veias e artérias, entre mim.

Convoco essas paisagens esvaídas: sou névoa, elas são névoa, somos um só estrangeiro nesse vácuo imenso. Ó reais medidas, ó rigoroso atlas, circundando de pólos e de mares, os teus marcos cintilam nos meus olhos enquanto os séculos pesam sobre as léguas. Claridades, apelos, entretantos, apesares e números e luzes; somos tudo, cabeça, tronco, membros.

Ó planos do meu ser comunicados!

(LIMA, 1958, p. 798)

Ao focalizar o aspecto social em Invenção de Orfeu, o poeta dá vazão ao seu espírito humanista e cristão. No entanto, este caráter participante não quer dizer que para ele, a poesia deva ter fins utilitários, pois se os tiver, deixaria de ser poesia. De acordo com Jorge de Lima (1958), a poesia de todos os tempos sempre teve importante função social, "já que o poeta foi sempre o anunciador das grandes reformas universais. Hoje, mais do que nunca, precisamos de poesia.” (LIMA, 1958, p. 71)

Ao adotar uma perspectiva revolucionária e renovadora para poesia, o poeta assume a missão de, em meio à decadência geral do mundo, trabalhar para restaurá-lo, porque "é dever do poeta recompor tudo" (LIMA, 1958, p. 75). Assim, o papel da poesia em face dos sofrimentos humanos pós-guerra é "elevar o nível dos corações, projetar as nossas mãos para consolar o distante companheiro aturdido pelas decepções da vida nos quatro pontos cardeais” (LIMA, 1958, p. 72). Desse modo, a poesia, no parecer de Jorge de Lima (1958), "recebe uma função importante no sentido de influenciar positivamente o mundo e até mesmo tem o poder de salvá-lo" (LIMA, 1958, p. 96). Jorge de Lima considera o Poeta um ser antenado e capaz de captar antecipadamente acontecimentos extraordinários, como são exemplares as figuras de Thomas Morus (2001), que com sua Utopia antecipou as revoluções do mundo moderno em pelo menos quatro séculos e de Ovídio (200o), que nas Metamorfoses disse: "Nada se perde, nada se cria na natureza; tudo se transforma", tese posteriormente confirmada por Lavoisier. 
Jorge de Lima (1958) repudia, em sua poesia, os acontecimentos históricos recentes ${ }^{11}$. Esse aspecto é também demonstrado pela tentativa de reencantar o mundo, no sentido de que o poeta pretende fazer sobreviver a poesia no mundo moderno ${ }^{12}$.

Na sequência do Canto,estância VI, vemos o fortalecimento do mundo imaginário através das presenças do poeta profeta "Diante do que entrevi resolvi desdenhar-me" (LIMA, 1958, p. 802), que pode prever acontecimentos, e de seres e objetos fantásticos como a exemplar figura mitológica do hipocampo (ser metade peixe e metade cavalo), imagem que nos remete perfeitamente a uma colagem surrealista.

O poeta deseja renovar-se, tirar de si tudo aquilo que considera maléfico. Nesse redimensionamento do ser ele percebe que as coisas superficiais e mundanas não têm o valor que se costuma dar: "e tudo o mais vaidade ou necessário vício/ ou cansaço vulgar ou paciente medo" (LIMA, 1958, p. 802). Ele quer ampliar sua visão das coisas e do mundo, está em busca da transcendência e é por isso que a partir da terceira estrofe desse fragmento seus versos se tornam

\footnotetext{
${ }^{11}$ Murilo Mendes mesmo se pronuncia a esse respeito em um de seus ensaios dedicado à interpretação de Invenção de Orfeu,Os trabalhos do poeta: "O que se acha em jogo em cima da mesa de operação e esta mesa de operação é o mundo todo - é a própria condição do homem, sua subsistência no presente e no futuro. A questão social transformou-se na questão mesma da humanidade. Não há distinção nítida de classes, não há mais adivinhação rigorosa da sociedade em dois campos políticos. Há em primeiro lugar a divisão do homem dentro de si próprio: a consciência desta divisão estende-se a todos. [...] Não se trata apenas, a meu ver, da transição de uma forma de sociedade para outra, declínio de uma classe e consequente subida a outra. É tudo isto e outras coisas mais. Opera-se uma revisão total das possibilidades do homem em face da natureza e do desconhecido. O poder político - penso particularmente no poder totalitário - é um dos personagens principais do drama: agravamento do terror, tentativa de exoneração do humanismo, eliminação das nossas tendências místicas e contemplativas, apelo à única força telúrica, e supressão da nossa intimidade fecunda para se criar, através de monstros métodos científicos, uma solidão estéril e desumana - o que determina o aparecimento de uma nova espécie de homem, o homem mecânico, o homem robot, o homem sozinho em face de um Estado e de um universo hostis, fautores de um permanente estado de sítio. Não creio que haja outro assunto mais próprio à meditação de um poeta de nosso tempo. Penso que tal assunto é de fato épico, alargando-se, repito, o conceito clássico." (MENDES, 1958, p. 127)

${ }^{12} \mathrm{Em}$ outro momento, Jorge de Lima também declara a sua crença no poder transformador da poesia: "A poesia aproxima constantemente os povos, separados pelas guerras, pela política, pelos regimes, pelos ódios, que são cordilheiras mais difíceis de transpor do que as comuns cordilheiras e as grandes serras que separam os povos da América do Sul. Vejo entre os povos da Europa, por exemplo, maiores cordilheiras intransponíveis, que são as cordilheiras da intolerância; estas cordilheiras são, em verdade, muito maiores do que os nossos Andes, que as nossas serras do Mar, que os nossos rios, que os nossos acidentes de fronteira, separatórios, aparentemente separatórios." (LIMA, 1958, p. 97)
} 
cada vez mais densos e enigmáticos, carregados de simbolismo e de imagens fantásticas.

Diante do que entrevi resolvi desdenhar-me e apagar de meu corpo o que houvesse de mar: o seu sal, o seu choro inconsciente, até mesmo. O minúsculo hipocampo e outras coisas e redes.

Sei que eu era capaz de tamanho suicídio Pois que a vida parece uma breve centelha, E tudo a mais vaidade ou necessário vício Ou cansaço vulgar ou paciente medo.

Para esquecer ergui as mãos e por instantes Apertando o ar da terra abafado e constante Tive alguma ilusão, vinham seivas recentes, Vestígios, abstrações, ou rangiam-me os dentes.

Sempre é melhor a flora expansiva e invitada, Dir-se-ia uma atriz amainando leopardos Enquanto com uma luva arrebanham libélulas; Tudo é encantado na atriz que se reverte em mágica.

Certos dias segui as renas legionárias arrastando em seu leite uns tipos ofegados que das selvas os leões espreitavam suspensos na seivosa begônia enorme como um poema. (LIMA, 1958, p. 802)

O poeta diz estar em busca "[...] de um ouro em que tudo se oculta”(LIMA, 1958, p. 803), o que parece representar algo poderoso e simbólico, uma espécie de artefato ou lugar onde tudo está contido, que engloba a totalidade humana e que também demonstra o seu desejo de recuperar a totalidade.

$\mathrm{Na}$ sequência dessa estância, o poeta deseja assumir a feição do deus órfico.

Mendigo de pedir retorno a ser, ó Deus! E peço-te Lenora, e peço-te meu canto! E eu próprio fique em minha enodoada bandeja pedindo um níquel para uma fumigação.

Estendo as mãos pedindo, estendo os pés nos lagos, purifico-me em bíblia, arrependo-me em vida; com uma sonda no umbigo alimento-me de escassas migalhas que introduzo em seu canal esguio.

Mas se eu soprar por essa enguia assumo logo a feição do deus órfico. É um lunar pavio 
incendiando o torpor de meu tão longo exílio

vindo dos céus de lava em favor de meus rogos. (LIMA, 1958, p. 804)

Neste fragmento vemos a associação de Orfeu ao Cristianismo. É após a purificação do poeta pela Bíblia e pelo arrependimento de seus pecados que Ele (um pedinte, mendigo, ser insignificante frente o poder divino) pode assumir a figura de Orfeu e os seus pedidos serem atendidos. O descimento do poeta à figura humilde do pedinte aponta também uma contraposição do poema de Jorge de Lima (1958) à figura dos heróis das epopeias clássicas. Ao se posicionar dessa maneira vemos claramente que a realização da poesia em Invenção de Orfeu está sujeita não somente à própria vontade do poeta, mas ao julgo e à inspiração divina. Sem esses pressupostos, ou apenas com a utilização do pensamento puramente racional, não é possível a feitura do poema.

A estância XIII nos proporciona uma espécie de síntese das principais temáticas presentes em todo o poema: a situação insólita ("a mão sem braço" (LIMA, 1958, p. 808)); a imagem das musas (Lenora e outras); o estado de transe, de loucura e o insólito que dificultam a compreensão dos versos ("que loucura o escureceu" (LIMA, 1958, p. 808)); a memória (o tecido da memória é feito das lembranças recalcadas do poeta); o ambiente noturno ("noites claviculares" (LIMA, 1958, p. 808)); a epopeia sem heróis, contraposição ao sentido clássico do termo ("epopeia sem guerreiro" (LIMA, 1958, p. 808)).

E esse velho e atroz poema?

Quem acaso o arquitetou?

Que mão sem braço o escreveu?

Que Lenora os mereceu?

Que mulheres vivem nele?

Que loucura o escureceu?

Ó tecido de memória recuadas de meu tempo que a eternidade comeu! Ó noites claviculares, epopeia sem guerreiro, humana sobrevivência das lembranças recalcadas, cem avós em cada cântico prévio nunca amanhecido.

Deixai-me nele. 
Invenção de Orfeu conserva uma estreita relação com a lenda de Orfeu. Jorge de Lima (1958) ao elaborá-lo se apropria do mito de Orfeu, o primeiro poeta e o pacificador da natureza, que mediante seu canto possibilita a criação de um novo mundo por meio da crença no poder restaurador da palavra. Assim, o poeta tenta recompor o mundo original através da volta a um tempo mítico, em que a palavra recebe um caráter mágico e transformador, características estas também próprias da poesia moderna. Nesse sentido, o poema de Jorge de Lima relacionará o mito à poesia de maneira intrínseca.

Serão somadas a Invenção de Orfeu outras características próximas e/ou semelhantes às do orfismo, aprofundando o caráter próprio do mito de Orfeu (a imaginação criadora, o encanto, a multiplicidade, etc.) acrescendo, ao poema, a perspectiva órfica de sua construção a partir de outras temáticas representadas pelo elemento onírico, a memória e o mundo lúdico, principalmente provindos do imaginário infantil, e o desejo de recriação e/ou reencontro do mundo perfeito em sua ilha mítica.

A estância XIV representa, de forma ampla, o paraíso conquistado pelo poeta-órfico por meio de um grande número de imagens-símbolos que o estruturam (ilha, mar, nuvens, aves, serpentes, cavalo, porcos, pássaros, tigre, diabo, fogo, chuva, cruz, criança, Eva, Pia, etc.). É mais um poema síntese de Invenção de Orfeu, onde convergem, numa visão panorâmica, o sentido de todo o poema. Nesse momento, a ilha representa, como figura de base, o símbolo global do humano e do divino. A ideia principal do poema é da comunhão através da dualidade característica do ser humano (o corpo e alma, morte e vida).

A mensagem final do poema é claramente posta em sua última estrofe, quando o poeta relembra o ato batismal pelo qual o homem obtém a vida eterna e que também, de certa forma, se torna criança novamente. $\mathrm{O}$ que realmente o poeta almeja é a fé (“Fidem” (LIMA, 1958, p. 808)) e a vida eterna ("Vitam aeternam" (LIMA, 1958, p. 808)). Esta comunhão total (divina e humana) é obtida por meio da união entre os mundos natural e o sobrenatural. Nessa perspectiva, a 
poesia é alcançada pela Graça divina que capacita o poeta (o homem) a captar a perenidade. Desse modo, o paraíso perdido, o Éden, é recuperado pela poesia.

Maduro pelos dias, vi-me em ilha, porquanto,

como conhecer as coisas senão sendo-as? Como conhecer o mar senão morando-o? Às coisas Deus um dia nos recuou. Contemplo as nuvens. Elas me rociam.

Refletem-se em meu sangue: nuvens e aves. À sombra de meus pés reptam-se serpes.

Quantas selvas escondo! Sou cavalo, corro em minhas estepes, corro em mim, sinto os meus cascos, ouço o meu relincho, despenho-me nas águas, sou manada de javalis; também sou tigre e mato; e pássaros, e voo-me e vou perdido, pousando em mim, pousando em Deus e o diabo. Nasço na floresta, grasso grandes pestes, Porquanto, jazo em mim mesmo, vejo-me, reflito-me. Sei dos pássaros, sei dos hipopótamos, sei de metas, de idades, aconteço-me, embebo-me na chuva que é do céu, abraso-me no fogo dos infernos. Porquanto, como conhecer as coisas senão sendo-as? Abrigo as minhas musas, amam sobre. Aflijo-me por elas, sofro nelas, encarno-me, em poesia, morro em cruz, cravo-me, ressuscito-me. Petrus sum. Sou Ele mas traindo-o, mas em burro, com esses cascos na terra, e ventas no ar, cheirando Flora; minhas quatro patas rimam iguais, forradas, alforriadas, burro de Ramos, levo sobre o dorso Alguém em flor, Alguém em dor, Alguém.

Contudo, burro épico, vertido para crianças, transporto-as à outra margem, seu Cristóvão Colombo, sou columba, Deus Espírito que desce sobre o início, sou palavra antes de mim, eu evo. Ave Maria, Eva sem culpa, tem de mim piedade, Pia sacramental de que emerjo ilha. _ Quid petis ab Ecclesia Dei?

$$
\text { - Fidem. }
$$

_ Fides, quid tibi proestat?

_ Vitam oeternam.

(LIMA, 1958, p. 808) 
Outro ponto importante presente nesse poema se refere ao possível significado do verso "como conhecer as coisas senão sendo-as" (LIMA, 1958, p. 8o8), repetido por duas vezes. Este verso parece sintetizar a poética encerrada em Invenção de Orfeu, no sentido de que o poeta expressa, como também queriam os surrealistas, seu desejo utópico de abolir a distância entre a linguagem e as coisas e a linguagem e os homens. Com o auxílio de Raymond (1997) compreendemos bem o significado do verso de Jorge de Lima (1958) pois, para o crítico, na poesia de vários poetas místicos modernos se apresenta a ideia de que o conhecimento verdadeiro exige a ruptura do sujeito com o objeto.

\begin{abstract}
Partindo do exame de um grande número de textos de poetas místicos e metafísicos, de João da Cruz a Novalis, Nerval, Poe, Baudelaire, Rimbaud e sobretudo Mallarmé, confia ele ao poeta as prerrogativas que entrevia este último, a missão de trazer a explicação órfica da Terra. Persuadindo com razão de que o conhecimento verdadeiro exige a ruptura de todo o limite entre o sujeito e o objeto, que ele é o divino, que a tarefa é a de reintegrar o Absoluto, que ser Verbo, agindo sobre o real a ponto de transformá-lo, de superá-lo. Possuir as chaves é abrir a porta de marfim ou roubar o fogo divino. E é sem dúvida que se voltam os poetas em sua busca dessa poesia-conhecimento integral. Mas creio que esse desejo é precisamente impossível e que nele reside o drama da poesia. Ela manifesta uma das reivindicações mais elevadas do homem, mas não receberá nunca outra resposta que sua própria; não saberá nunca se a grande esperança é satisfeita ou frustrada. (RAYMOND, 1997, p. 310-311)
\end{abstract}

O projeto de Jorge de Lima em Invenção de Orfeu parece concordar com a proposição de que a poesia pode mudar o mundo e a vida, utilizando-se de uma espécie de ética metafísica e poética que busca a reconquista do paraíso perdido pela Queda. Mas como aponta Marcel Raymond (1997), este estado afortunado, “'perfeito e pleno', inefável em si mesmo é também efêmero. Seu desaparecimento deixa ao homem uma consciência mais viva de seus limites e das condições de uma vida precária." (RAYMOND, 1997, p. 13) E é por isso que o homem/poeta "só terá repouso quando tiver novamente forçado as portas do Paraíso" (RAYMOND, 1997, p. 13). Para isso, o poeta/herói recorrerá à memória desse tempo mítico, buscando o êxtase desse tempo perdido que deseja recriar “pelo verbo, a felicidade perdida” (RAYMOND, 1997, p. 13). É, nesse sentido, que 
no poema "Toda imagem se organiza, secretamente, em símbolos; as palavras cessam de ser signos para participar das próprias coisas, das realidades psíquicas que evocam.” (RAYMOND, 1997, p. 13-14) Para Jorge de Lima (1958), não há outra maneira de conhecer as coisas senão sendo-as, desejo utópico que encerra Invenção de Orfeu.

\section{Referências}

APOLlinAIRE, Guillaume. O Bestiário ou Cortejo de Orfeu (Trad. e Apres. Álvaro Faleiros). São Paulo: Iluminuras,1997.

ARTE E PALAVRA: ORFEU. Fórum de ciências e cultura UFRJ-IDEA (Vol.4) Rio de Janeiro: UFRJ/FCC, 1984.

AURÉLIO. Buarque de Holanda Ferreira. Novo dicionário Aurélio da língua portuguesa. Rio de Janeiro, Nova Fronteira, 1986.

BRANDÃO, Junito de Souza. Mitologia grega. Vol. II. Petrópolis: Vozes, 1996.

CAMPANELLA, Tommaso. A cidade do sol. In: Os pensadores - Giordano Bruno, Galileu Galilei, Tommaso Campanella.São Paulo: Abril Cultural, 1983.

CAVALCANTI, Luciano Marcos Dias. Invenção de Orfeu: a "utopia” poética na lírica final de Jorge de Lima. São Paulo-Belo Horizonte, Todas as Musas/FAPEMIG, 2015.

DETIENNE, Marcel. A escrita de Orfeu. (Trad. Mário da Gama Kury). Rio de Janeiro: Jorge Zahar, 1991.

LIMA, Jorge de. Obra Completa (Org. Afrânio Coutinho). Rio de Janeiro: Aguilar, 1958.

(Org. Ana Maria Paulino). O Poeta Insólito: fotomontagens de Jorge de Lima. SP: IEB/USP, 1987. 
MENDES, Murilo. Invenção de Orfeu: A luta com o anjo; Os trabalhos do poeta. In: Obra Completa (Org. Afrânio Coutinho). Rio de Janeiro: Aguilar, 1958.

MONTEIRO, Adolfo Casais. A palavra essencial: estudos sobre a poesia. São Paulo: Cia. Editora Nacional/EDUSP, 1965.

MORUS, Thomas. Utopia. (Trad. Paulo Neves) Porto Alegre: L\&PM, 2001.

OVÍDIO. As metamorfoses. (Trad. Bocage). São Paulo: Hedra, 2000.

PAUlinO, Ana Maria. Jorge de Lima - Artistas Brasileiros (Poesia e Pintura). São Paulo: EDUSP, 1995.

RAYMOND, Marcel. De Baudelaire ao surrealismo. São Paulo: EDUSP, 1997.

RIMBAUD, Jean-Arthur. O Barco bêbado. (Ed. Bilíngue - Trad. Pedro José Leal) Lisboa: Hiena, 1995.

TRINGALI, Dante. O Orfismo. In: CARVALHO, Sílvia M. (Org.). Orfeu, Orfismo e Viagens a Mundos Paralelos. São Paulo: Edunesp. 1990.

*Doutor em Teoria e História Literária pela UNICAMP. Realizou estágio de pósdoutorado no Departamento de Literatura Brasileira da UNESP/Araraquara (2011-2013). 